\title{
The Effects of CLIL Education on the Subject Matter (Mathematics) and the Target Language (English)
}

Khalid OUAZIZI*

\begin{abstract}
This paper investigates the effects of Content and Language Integrated Learning, CLIL for short, on both the attainment of the subject matter, mathematics in our case, hence the content aspect of CLIL. The second axes of research focuses on the effect of CLIL on the learners' proficiency vis-à-vis the language of instruction, epitomized here by English- hence the linguistic aspect of CLIL education. This paper adopts a multiple approach methodology to deal with the research questions at hand. I concluded on the basis of field work, this includes data coding and analysis, questionnaire design and analysis, an administered mathematical test, and the teacher's continuous assessment of his students, that CLIL education is more effective than traditional educational systems in helping learners to achieve high proficiency levels in the target language (English) and to attain high levels of competence in the subject matter (mathematics). I believe these results might be explained by an existing of a covert tradeoff between the brain mechanisms involved in learning both mathematics and languages as well as by the pedagogical opportunities, provided by CLIL environment, and which echo, to a great extent, L1 acquisition environment.
\end{abstract}

Key words: CLIL; multilingualism; cognition; mathematics; English.

\footnotetext{
Vrije Universiteit Brussels \& The New High School Tata, Belgium

Corresponding author: kouazizi@vub.ac.be
}

Received: 2015-06-17 / Sent for peer review: 2015-08-06 / Accepted by peers: 2016-03-18 / Approved: 2016-06-24

To reference this article in APA style / Para citar este artículo en APA / Para citar este artigo

Ouazizi K. (2016). The Effects of CLIL Education on the Subject Matter (Mathematics) and the Target Language

(English), 9(1), 110-137. doi:10.5294/laclil.2016.9.1.5 


\section{Los efectos de la educación AICLE en la materia en cuestión (matemáticas) y la lengua objetivo (inglés)}

\section{Resumen}

Este artículo investiga los efectos de aprendizaje integrado de contenido y lenguas extranjeras (AICLE), tanto en la consecución de la materia, las matemáticas en nuestro caso, como también en el aspecto del contenido de AICLE. El segundo eje de investigación se centra en el efecto de AICLE en la competencia de los alumnos cara a cara a la lengua de instrucción, personificada aquí por el inglés, el cual hace parte del aspecto lingüístico de la enseñanza CLIL. En este trabajo se adopta una metodología de enfoque múltiple para hacer frente a las preguntas de investigación que nos ocupan. Se concluye - sobre la base del trabajo de campo, esto incluye la codificación de datos y su análisis; el diseño y el análisis del cuestionario; una prueba matemática administrada, y la evaluación continua de los maestros a sus estudiantes- que la educación AICLE es más eficaz que los sistemas tradicionales de educación para ayudar a los estudiantes a lograr altos niveles de competencia en el idioma objetivo (inglés) y para alcanzar altos niveles de competencia en la materia (matemáticas). Estos resultados podrían explicarse por la existencia de un intercambio oculto entre los mecanismos del cerebro implicados en el aprendizaje de las matemáticas y los idiomas, así como por las oportunidades pedagógicas, proporcionadas por el entorno AICLE, y que hacen eco, en gran medida, en el ambiente de adquisición de L1.

Palabras clave: CLIL; el multilingüismo; la cognición; matemáticas; inglés. 


\section{Os efeitos da Aprendizagem Integrada de Conteúdos e de Língua em matemática e a língua-alvo (inglês)}

\section{Resumo}

Este artigo pesquisa sobre os efeitos da Aprendizagem Integrada de Conteúdos e de Língua (AICL) tanto na realização da matéria, nesse caso a matemática, quanto no aspecto do conteúdo da AICL. O segundo eixo de pesquisa se centraliza no efeito da AICL na competência dos alunos ante a língua de instrução, personificada aqui pelo inglês, que faz parte do aspecto linguístico da AICL. Neste trabalho, adota-se uma metodologia de abordagem múltipla para responder às perguntas de pesquisa propostas. A partir do trabalho de campo, que inclui a codificação de dados e sua análise, o desenho e a análise do questionário, uma prova de matemática administrada e a avaliação contínua dos docentes a seus estudantes, conclui-se que a AICL é mais eficaz do que os sistemas tradicionais de educação para ajudar os estudantes a atingirem níveis de competência na língua-alvo (inglês) e em matemática. Esses resultados poderiam ser explicados pela existência de um intercâmbio implícito entre os mecanismos do cérebro implicados na aprendizagem de matemática e de idiomas, bem como pelas oportunidades pedagógicas proporcionadas pelo contexto da AICL, que refletem, em grande medida, no ambiente de aquisição de L1.

Palavras-chave: AICL; multilinguismo; cognição; matemática; inglês. 


\section{INTRODUCTION}

Considering its prevalence in the world's population, (bi) multilingualism is the norm whereas monolingualism is the exception (Baker \& Prys, 1998). It is estimated that there are more than 7000 languages spread over only 206 states acknowledged by the United Nations. However, despite this reality fact, when it comes to language teaching and pedagogical matters, multilingualism was considered, until recent years, as a serious threat to children's cognitive development and educational success because it was thought that multilingual learners are, in comparison to their monolingual peers, poor in vocabulary, poor in writing skills, and show more error prone in grammatical tasks (Van de Craen et al. 2007:1).

Nowadays, since the publication of Peal and Lambert's (1962) study which demonstrated that bilinguals score better than monolinguals on verbal and Non-verbal tests (cf. Van de Craen et al. 2007), the way multilingualism is viewed changed dramatically. A (bi)multilingual brain is now viewed as a rich brain that contains two or more linguistic systems rather than the traditional idea 'one mind one language'. This dramatic change is indeed the fruit of the emerging of new neuro-imaging techniques such as: Functional Magnetic Resonance Imaging (FMRI), Structural Magnetic Resonance Imaging (SMRI), Positron Emission Tomography (PET), and Magnetoencephalography (MEG) ..., to name but few.

The current study, described from a general perspective, is part of the -almost settled-debate on monolingual versus multilingual education. More specifically, it investigates the effects of learning a subject matter, mathematics particularly, through a foreign language, English specifically, on both subject matter competence and language proficiency. In a more restricted view, this study is embedded within the research program developed by the languages department at the Vrije Universiteite van Brussel, henceforth VUB, on multilingualism and Content and Language Integrated Learning (CLIL). CLIL, as will be explained in more extensive manner in the subsequent sections, is a new paradigm of education whose basic idea is based on teaching/learning a subject matter through a foreign or second language. 
In the light of the CLIL program developed at the VUB, I choose to investigate the complicated relationship between multilingualism and both subject matter (mathematics) competence and language proficiency (English). To paraphrase these statements in research questions:

1. Does CLIL education lead to better language proficiency in the target language compared to traditional approaches?

2. Does CLIL education lead to better subject matter knowledge than traditional learning?

Consequently, I hypothesize that: (i) Yes, CLIL education will result in better language proficiency than traditional approaches, and (ii) Yes, CLIL education will lead to better subject matter knowledge than traditional learning.

Methodologically, I opt to answer the research questions through field work study, which is also called ethnography. The field work involves an internship at the School of Stedelijke Humaniora, henceforth $\mathrm{SH}$, in Dilsen and the Koninklijk Atheneum Etterbeek School, henceforth $\mathrm{KAE}$. The role of KAE is limited to the fact that it is used only as a control group for my experiment test I carried out in $\mathrm{SH}$, and also to the fact that I used it (KAE) throughout the whole study as a parallel example to compare it with CLIL education paradigm. In addition, an experimental test was designed in order to verify empirically the achievements of students, both the target and control groups, in the subject matter namely mathematics.

The structure of this paper is twofold: (1) a background section to review the CLIL program. Under this section, I will discuss (1.1) what is CLIL education?, (1.2) the underlying learning mechanisms of CLIL education, (1.3) neurolinguistic aspects of mathematics and language, and (1.4) language policy of SH. In the second section, I will discuss and report the tasks of my internship at the SH. Under this section, I will report (2.1) data recording and analysis, (2.2) questionnaire design and analysis, (2.3) mathematical test, (2.4) teacher's continuous assessment, and (2.5) a discussion of the results. 


\section{BACKGROUND}

\section{What is CLIL education?}

Content and Language Integrated Learning- or simply CLIL- is, according to Van de Craen, Ceuleers and Mondt (2007a), neither a method of teaching nor a pedagogical technique; rather it is a new paradigm of education in that it (CLIL) fosters a completely new concept of learning whose basic idea is based on teaching/learning a subject matter through a foreign or second language. Put in different words, CLIL integrates the teaching/learning of the subject matter with the teaching/ learning of a language although the former is taught/learned explicitly and the latter implicitly.

According to Van de Craen et al. (2008), the idiosyncratic aspects and characteristics of CLIL education have farfetched consequences on the architecture of educational system at almost all levels referring to pedagogical, school structure, language policy, or cognition. As such, it (CLIL) qualifies to be an innovative paradigm of the education that positively affects the pedagogical methods and techniques applied in classrooms, language policies at the level of schools, and language management in society as a whole.

In brief terms, the CLIL research program lies on six tenets and research questions which distinguish it from other types of education whether we consider subject matters learning or languages learning. In the following paragraphs I will describe the six tenets, hence research lines, of CLIL education as developed by Van de Craen et al. at the Vrije Universiteit of Brussels (See Van de Craen et al., 2007a,b,c).

Tenet 1. Does the CLIL approach lead to a better language proficiency in the target language compared to traditional approaches?

The answer to this question is yes, i.e., students in CLIL education develop a very strong competence in the target language particularly in the pragmatic aspect of using language. One of the main reasons behind this success is due to the fact that CLIL education presupposes a lot of practice of the theme taught, mathematics in our case. Hence, benefiting from the golden learning rule "use it or lose it", paraphrased in the ordinary language as "practice what you preach" (Admiral et al., 2006). 
Tenet 2. Does CLIL lead to improve first language development compared to traditional approaches?

The studies, to name but a few (Genesee, 2003), carried out in the light of this question reported that CLIL has no negative impact on the mother tongue development. If anything, the influence is positive (Van de Craen et al., 2008).

Tenet 3. Does CLIL lead to better subject matter knowledge than traditional learning?

According to Van de Craen et al. (2007), the answer to this question is yes. A subject matter in the CLIL environment seems to be boosted especially in primary school than in secondary education.

Tenet 4. In what way does CLIL influence attitudes and motivation towards languages and language learning?

Although few studies carried out to answer this question the state of the art suggests that younger learners have high positive attitudes and motivation to learn languages in CLIL framework. Adolescents are less positive yet the results are positive (Ceuleers et al., in print).

Tenet 5. In what way does CLIL influence cognitive development as compared to traditional language learning?

The answer to this question is related to the factor of age, i.e., "the younger the better". That is to say, student who starts learning a subject matter in a foreign language early score better results than older ones. In general, CLIL leads learners to be more cognitively active (Bialystok, Craik, \& Freedman, 2006; Bamford and Mizokawa, 1991).

Tenet 6. How does CLIL affect brain development as compared to traditional language learning approaches?

The results show that the brain organization of bilinguals in general (applying to CLIL students too) is different than monolinguals in the sense that they (bilinguals) perform some cognitive tasks more efficiently than monolinguals; for example, they are good at developing meta-linguistic concepts (Bialystok, 2005).

\section{The underlying learning mechanisms of CLIL education}

According to Van de Craen et al. (2008) CLIL practice shed light on many interesting findings regarding learning mechanisms underlying CLIL 
education that affects the learners and as a result creates a different kind of learner. In this section, I will summarize the main ideas of the principles underlying CLIL education which were discovered through extensive and long term research by Van de Craen and his colleagues at the VUB.

The principle of repetition: in CLIL education the learners usually redo the same syllabus they have learned already in their mother tongue. This repetition has a paramount effect on enhancing memorization and strengthening it. The principle underlying such practice is "practice makes perfect". However, a point in order is needed here, the concept of repetition as used in CLIL is different from the conventional one, i.e., in CLIL education repetition involves innovation and expansion in that though the same syllabuses are taught again. They are taught in new forms and its content is extended to cover more in-depth topics.

The principle of transfer: this principle amounts at the fact that the knowledge of one thing may help to facilitate acquire something else. It was discovered by Van de Craen et al. (2008) while they were observing French L1 pupils who first learned to read in Dutch and later moved to read in French. The astonishing result is that the same group did better than the control group who started learning French from beginning in French. This unexpected result was due the fact that Dutch has a 'transparent relationship', unlike French which has an opaque system, in its grapheme-sound relationship and that helped the pupils to crack the alphabet code quickly and more efficiently.

The principle of addition: as a matter of fact, CLIL education is based on learning additional languages beside L1. This practice has very interesting consequences on learning languages in general in that, like in music and sport, the more a learner learns a new language, the easier it becomes for him/her to learn another language.

The principle of enhanced cognitive development: studies carried out by Van de Craen et al. (2008) on the mother tongue, target language and performance on math tests revealed that the pupils' pragmatic language use and mother tongue knowledge are enhanced and that the performance on math tests are better than monolinguals. Nevertheless, research on the relationship between language use and cognition is still needed to settle down this issue. 
The principle of brain stimulation: it is witnessed that CLIL education has an added value on boosting cognition, i.e., it is self-evident in neurosciences now that brain simulation affects the brain structure. That is to say, learning an additional language beside the content of the subject matter assimilates the brain in a highly positive way and that, in its turn, results in restructuring the brain neuronal networks. The neuronal mechanism underlying such operations is "Neurons that fire together wire together" (Schatz, quoted by Marsh et al., 2009) and the learning pattern is called "hebbian learning" (Van de Craen et al., 2008).

Putting these principles together leads into emerging a new 'emergence pattern of learning' whose principal idea is based on learning a low-level activity (learning in foreign language) that results in higher-level sophistication (greater brain activity and self-organization) (Van de Craen et al. 2008).

\section{Neurological aspects of mathematics and language}

From a neurological perspective, there are differences among scholars about the brain regions and cognitive mechanisms and networks involved in mathematical thinking. According to Dehaene, Spelke, Pinel, Stanescu, and Tsivkin (1999) and McLean and Hitch (1999) visual-spatial, linguistic, and working memory skills are essential for mathematical reasoning. Also, semantic or declarative knowledge of mathematical facts is important for doing math computations (Byrnes, 2001). In addition, mathematical reasoning requires also the involvement of procedural knowledge to carry out math operations and understanding of math's syntax development (Hiebert and LeFever, 1987).

Neuroimaging of math competencies show that the prefrontal and inferior parietal areas (including the angular and supramarginal gyri) are the most prominent areas involved in math computation skill (Burbaud et al., 1995; Cowell et al., 2000). As such, mathematical competencies share with language some parts of the brain network involved in processing information especially when language comprehension involves tasks related to metaphorical understanding and the interpretation of indirect language like implications. 


\section{Language policy of Stedelijke Humaniora}

In terms of the socio-cultural context of the internship, Stedelijke Humaniora is a school institution situated in Dilsen, in the Flanders region. $\mathrm{SH}$ includes first, second, and third grades as it is explained in its official webpage (http://www.sh-dilsen.be/joomla/). In SH various subject matters such as (Mathematics, Physics, Biology, Culture, History, Sport, Dutch, English, and French...etc.) are taught.

What is special about here is that it adopts CLIL as its language policy, i.e., it allows teaching subject matters through foreign languages (English in our case). In general, there are five languages, namely Dutch, French, English, German, and Latin, are taught in SH school, although Dutch remains the dominant language of all students (http://www.sh-dilsen.be/ joomla/). All CLIL students study four hours a week in CLIL: two hours for mathematics and two for physics. In parallel, they were taking 6 hours a week of mathematics in their mother tongue (Dutch). These restrictions on language use are dictated by the Belgium law.

\section{FIELD WORK STUDY}

\section{Data recording and analysis}

In my treatment of the first research question posted in the introduction namely: Does the CLIL approach lead to a better language proficiency in the target language compared to traditional approaches? I have recorded 49:40 minutes of the speech interactions between students and their teacher. The stream of voice recorded involves various speech activities, such as introducing the intern, checking students' presence, teacher's explanations ...etc.; these activities are not related directly to what I want to assess during this task, i.e., the fluency of the students' linguistic output. Therefore, I have extracted out all the unnecessary data which is not directly related to the students' linguistic output.

Methodologically, I followed the very basic version of data coding as described by Du Bois et al. (1993), and Edwards (2007). My choice of this transcription style stems from the fact that I am interested merely in the grammaticality or ungrammaticality of the students' outputs par- 
ticularly in English. For a detailed transcription of the students' speech see appendix 1.

From an external perspective, I have noticed that during the period I spent with the students, the teacher has almost no problem whatsoever to talk in English, being it in general discussion related to schedule and holidays or technical discussion related to mathematics, with his students. This was clear to me from their ability to pursue what the teacher was telling them and from their relevant and to the point feedbacks.

More specifically, during the lesson in which the students have to correct their previous exercises on geometrical sequences, I was struck by two proper language issues that were raised during the discussions and interactions, some of the students could not understand the meaning of words "contribution" line 12 and "subsequence" line 31. Suddenly, everyone present in the class became part of this definition task: First, one student provided the translation into Dutch -bijdrage and opvolgend- but that did not satisfy the teacher who went to check the words definition in the online dictionary and while he was doing that everybody was adding and editing the meaning of the words under until everybody got its meaning in both English and Dutch. Simple as it may seem, the way students and teacher dealt with this fundamental step in the learning process (paying attention to concepts and their definition) of both the language and subject matter (mathematics) is really magnificent. Technically, in applied linguistics terms, this way of learning is called 'shared or collective learning'. It is one of the most efficient ways to learn new concepts. It is also a good example of 'scaffolding' learning, incidentally.

Furthermore, in my error analysis, of the whole speech stream I recorded, I could not identify any grammatical or spelling errors. The only error pattern, if I may call it that, is the presence of incomplete sentences as it is the case in sentences $2,6,8,10,14,16,25$...etc.. However, I think that it might be explained by the fact that language in online speech is different from language in formal settings like writing and delivering a speech during a ceremonial event. In other words, it is a normal characteristic for spoken language to be incomplete, like in lines 2, 4,10 ...etc. and to bear hesitations, like in line 18, because interlocutors take speech over from each other. Indeed, this might be explained by the fact that the interlocutors 
get involved in a different syntax and different way of speaking called 'dialogical syntax', i.e., one speaker starts a sentence, the other one finishes it. As such these speech phenomena are not mistakes but different ways of speaking and practicing language. All in all, the students seem to enjoy a balanced level of proficiency in English that permits them to study mathematics in English easily and efficiently.

\section{Questionnaire Design}

In the questionnaire design, I focused basically on the following three issues: (i) attitudes of students towards learning mathematics through English before and after CLIL, (ii) students aptitude/proficiency in English before and after the CLIL experience, and (iii) students' use of English outside the classroom. The rationale behind my choice of these three aspects is due to the fact that they are related indirectly to each other, i.e., I assume that if the student A has changed his/her attitude towards learning mathematics in CLIL's environment that his proficiency will (de)increase in correlation with his/her attitude, and in its turn, if the same student A becomes more proficient in English and more confident in his/her English, he/she must be able to use English outside the classroom. The results of the questionnaire came as follows:

In sum, what is strikingly remarkable about these data is that there is no single student whose attitude changed from positive to negative during his/her experience with CLIL education. Instead, we notice that all students' attitudes either changed from neutral to slightly positive or they maintain a positive attitude. Also, we can see that all the students' English aptitude has either enhanced from average to good/very good or they maintain a good level in English. Actually, student 6 has ameliorated his level from good to very good. Consequently, we notice that all students, except number 7, started using English outside the classroom with their teachers and friends, a sign that shows that they are confident in their linguistic competence.

\section{Mathematical test}

Carrying out the test was the primarily task of the study because it is able to demonstrate in concrete terms and without recourse to mere specu- 


\section{Table 1: Students' attitudes towards learning mathematics in a CLIL environment.}

\begin{tabular}{|l|l|l|l|}
\hline & \multicolumn{1}{|c|}{$\begin{array}{c}\text { Attitude before \& after } \\
\text { CLIL }\end{array}$} & $\begin{array}{c}\text { Language } \\
\text { aptitude before } \\
\text { \& after CLIL }\end{array}$ & \multicolumn{1}{|c|}{$\begin{array}{c}\text { English outside } \\
\text { classroom }\end{array}$} \\
\hline Student 1 & From N to slightly positive & From A to G & Sometimes with Ts \\
\hline Student 2 & Always positive & From A to G & Sometimes with Ts \\
\hline Student 3 & From N to slightly positive & Maintain G & Sometimes with Ts \& Fs \\
\hline Student 4 & Very positive & Maintain G & Often with Ts \& Fs \\
\hline Student 5 & From N to slightly P & Maintain G & Sometimes with Ts \& Fs \\
\hline Student 6 & Positive & From G to very G & Often with Ts \& Fs \\
\hline Student 7 & Very positive & From A to G & No \\
\hline Student 8 & From N to slightly positive & From A to G & Sometimes with Ts \\
\hline Student 9 & From N to slightly positive & Maintain G & Sometimes with Ts \& Fs \\
\hline Student 10 & From N to slightly positive & Maintain very G & Sometimes with Ts \& Fs \\
\hline
\end{tabular}

N: neutral, G: good, A: average, P: positive, T: teachers, F: friends.

lations the effects of CLIL education on the students' performance on the subject matter which is mathematics in this case. For the sake to render its results more relevant, transparent, and more informative, I used a control group. The control group consists of 20 students, seven females and 13 males, all aged between 15 and 16, only one is 17 . The members of this group have undergone their entire education in Dutch. Whereas, the CLIL group constitutes eleven students, 5 females and 6 males, all aged sixteen. One of the students, from Brazil, joined the school recently, was excluded from the test because he didn't manage to integrate in the rhythm, like other student, of what they are doing. As mentioned above, all CLIL students study two hours a week of CLIL mathematics beside 6 hours a week of mathematics in their mother tongue (Dutch).

More specifically, the mathematical test I used to test students mathematical competence was based on the syllabus followed by the teacher of KAE, i.e., the control group. The test, see appendix 3, is basically finding out the variable $x$ in the equations of the second grade called also quadratic equations. From an abstract perspective, this type of equations require high analytical capacities in that they presuppose that the student 
is familiar with various numerical calculations (operations) on fraction numbers, square numbers, natural numbers,...etc. and the knowledge (internalization) of various mathematical formulas.

Furthermore, quadratic equations presuppose a good mastery of mathematical as well as conceptual (linguistic) concepts such as the ability to recognize some tricky equations as quadratic equations without the presence of equal zero at the end of equation as it is the case in example (b) of the test: $4 X^{2}=-2 x$. The students must also be able to differentiate between different types of equations, which rather look more or less similar. Not least, they must also be fully aware of what 'an equation' is, in its conceptual being, meaning and entailment.

In the aftermath of the test, both teachers of SH school and KAE school corrected the assignments of the students. A ten-point scale was used. Also, notice that the size of the control group population is twice bigger than the target group, that's why it is important to look at the external as well as the internal statistical facts of both populations. The results of the test were as follows:

As we can see, described in general terms, both groups (CLIL and control groups) have achieved high scores on the mathematical test in that they both scored 4.15 and 2.8 above the absolute mean (5) respectively. Indeed, two students of each group have scored 10/10.

However, a close scrutiny to these results show also that CLIL's students achieved higher results than the control group when we take the mean score of each group separately: the mean of frequency distribution of CLIL student is 9.15 whereas it is only 7.8 for the control group. The standard deviation and variance of the target group is 1.24 and 1.55 respectively, and 1.24 and 1.56 for the control group respectively. That is to say they are almost exactly the same. However, if we consider the tenth student of CLIL, the one who scored 5.5, as an outlier, due to the fact that he misunderstood our (me and the teacher) instructions as he explained to us when the teacher was correcting his essay, the results of the high standard deviation scored will be completely changed and become 0.28 and variance 0.080. Indeed, the internal dispersion of the CLIL's group results is very insignificant in that they (except the tenth student) all scored above 9 out of 
Table2: Results of the mathematical test for CLIL and non-CLIL groupsIn order to make these data more transparent I represented them as a diagram.

\begin{tabular}{|l|r|r|}
\hline & CLIL group & Control group \\
\hline Student 1 & 10 & 10 \\
\hline Student 2 & 10 & 10 \\
\hline Student 3 & 9.5 & 9.0 \\
\hline Student 4 & 9.5 & 9.0 \\
\hline Student 5 & 9.5 & 9.0 \\
\hline Student 6 & 9.5 & 9.0 \\
\hline Student 7 & 9.5 & 8.0 \\
\hline Student 8 & 9.5 & 8.0 \\
\hline Student 9 & 9.0 & 8.0 \\
\hline Student 10 & 5.5 & 8.0 \\
\hline & & 8.0 \\
\hline Student 11 & & 7.0 \\
\hline Student 12 & & 7.0 \\
\hline Student 13 & & 7.0 \\
\hline Student 14 & & 7.0 \\
\hline Student 15 & & 7.0 \\
\hline Student 16 & & 7.0 \\
\hline Student 17 & & \\
\hline Student 18 & & \\
\hline Student 19 & & \\
\hline Student 20 & & \\
\hline Mean : & & \\
\hline
\end{tabular}

10. In contrast, the control group results show a bit high dispersion; their marks were between 10 and 5 .

Additionally, it seems to me that the most common error, specifically in the assignments of the control group, when dealing with quadratic equations comes from the fact that some students fail to conceive that equations in some cases allow two solutions (one positive and the other negative). This error was not witnessed in the target group (CLIL group) however. Conversely, the marginal errors attested in the assignments of the target group were due to the fact that they skip some steps or they use 


\section{Figure 1:Results of the mathematical test for CLIL and non-CLIL groups}

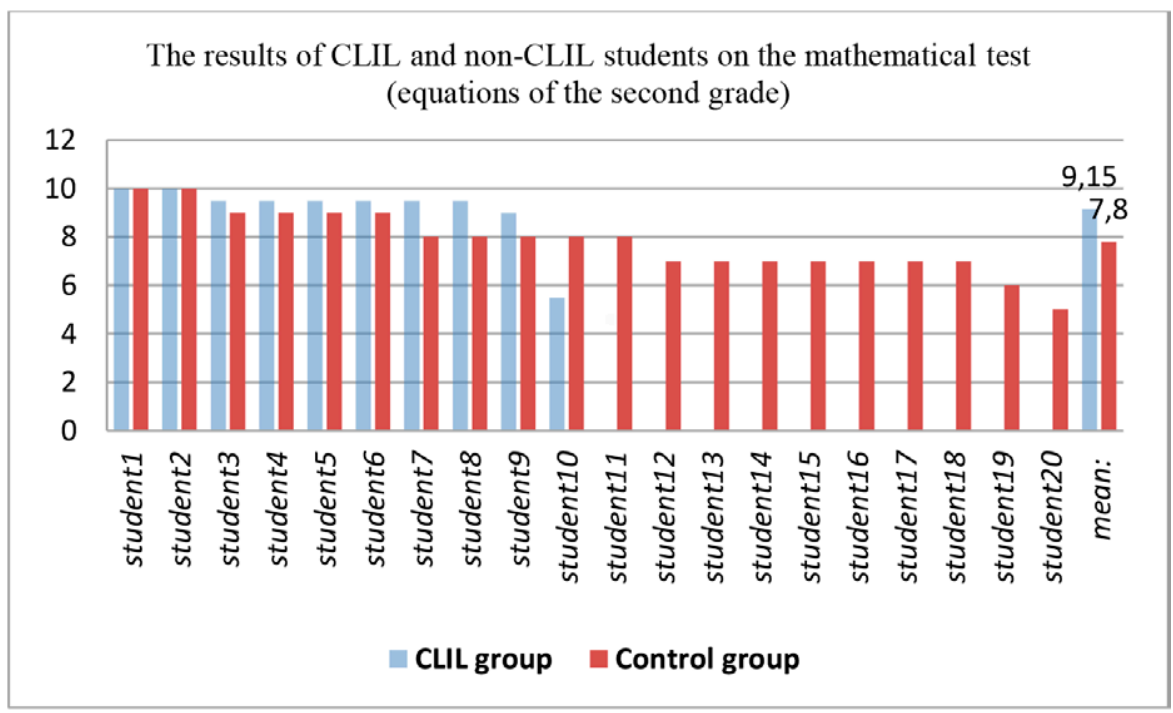

a Dutch word instead of English one. Notice also that language was totally excluded from the control group evaluation whereas the CLIL teacher insist on correcting students' language too.

\section{Teacher's continuous assessment report}

A priceless gift was given to me by the teacher during my internship at the SH school was that the teacher has kept a detailed analysis of all the work and assignments done by the student during the academic year 2012-2013, and which I would like to share its results with the reader.

As expected in an authentic CLIL education, the students of SH study both subject matter and language in an integrated manner. During the lessons, the students have been trained, and later assessed, to learn both mathematical themes (arithmetic sequences, geometrical sequences, proof direction inequality, recursive and explicit formula, ...etc.) beside language themes such as (translate into English, underline stressed syllable, plural formation, explain in English,... etc.).

For the sake of space restrictions, I will discuss in this thesis only the teacher's continuous assessment during the period 13.12.2012 till 08.02.2013 which coincides with my internship period. A complete review of the teach- 
er's continuous assessment, which covers 05.10.2012 until 08.02.2013, can be found in Appendix 4.

\section{Table3: Results of CLIL's group between period 13-12-2012 and 08-02-2013}

\begin{tabular}{|c|c|c|c|c|c|c|c|c|c|c|c|}
\hline $\begin{array}{c}\text { Results of CLIL's } \\
\text { group between } \\
\text { period 13-12-2012 and } \\
\text { 08-02-2013 }\end{array}$ & 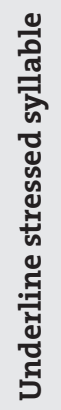 & $\begin{array}{l}\text { శ్లే } \\
\text { 밈 }\end{array}$ & 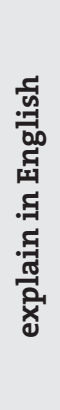 & 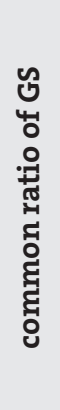 & 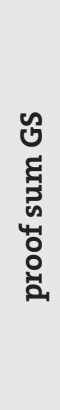 & 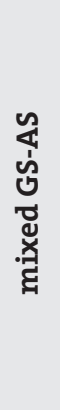 & 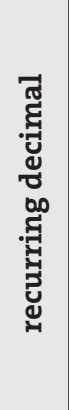 & 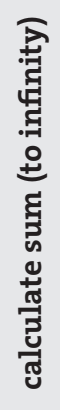 & 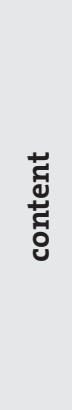 & $\begin{array}{l}\text { ๘ొ } \\
\text { శ్ } \\
\text { ప్ర } \\
\text { త్తు }\end{array}$ & 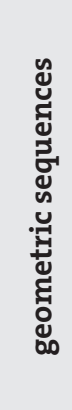 \\
\hline scale & 2 & 2 & 4 & 2 & 4 & 5 & 4 & 6 & 21 & 8 & ${ }^{*} 29$ \\
\hline student 1 & 1 & 1.5 & 1 & 0.5 & 3.5 & 5 & 4 & 3.5 & 16.5 & 3.5 & 20 \\
\hline student 2 & 2 & 2 & 1.5 & 1.5 & 3.5 & 5 & 4 & 3.5 & 17.5 & 5.5 & 23 \\
\hline student 3 & 1 & 2 & 0.5 & 2 & 3 & 3.5 & 3.5 & 4 & 16 & 3.5 & $19 \cdot 5$ \\
\hline student 4 & 2 & 2 & 3 & 2 & 3 & 5 & 4 & 5.5 & 19.5 & 7 & 26.5 \\
\hline student 5 & 1 & 2 & 3 & 1.5 & 3.5 & 5 & 0.5 & 2 & 12.5 & 6 & 18.5 \\
\hline student 6 & 2 & 2 & 3.5 & 2 & 3.5 & 5 & 4 & 3.5 & 18 & 7.5 & 25.5 \\
\hline student 7 & 2 & 2 & 3 & 2 & 3.5 & 4.5 & 4 & 4.5 & 18.5 & 7 & 25.5 \\
\hline student 8 & 1 & 1 & 3 & 1.5 & 3.5 & 4 & 4 & 4 & 17 & 5 & 22 \\
\hline student 9 & 2 & 2 & 3.5 & 2 & 4 & 5 & 3 & 4.5 & 18.5 & 7.5 & 26 \\
\hline student 10 & 0 & 2 & 2 & 1 & 4 & 5 & 3.5 & 4.5 & 18 & 4 & 22 \\
\hline Mean & 1.4 & 1.9 & 2.4 & 1.6 & 3.5 & 4.7 & 3.5 & 3.9 & 17.2 & 5.7 & 22.8 \\
\hline
\end{tabular}

As we can see in the table above the teaching method, hence evaluation, adopted by the teacher involves both language aspects and subject matter (mathematics) aspects: 4 elements related to language and 7 elements related to mathematics. The mean of each element, showed in the end line, in comparison to the absolute mean that can be obtained by the students, it is the total score divided on 2 , show that the students are scoring high marks: 0.4 above 1, 0.9 above $1,0.4$ above 2, 0.6 above 1, 1.5 above 2, 0.9 above $3,6.7$ above 10.5, 3.7 above 4 , and 8.3 above 14.5 respectively.

In overall, we may conclude, on the basis of substantial analysis, that CLIL education helps students, at least the current population in this sam- 
ple, to attain good results in both language learning and subject matter competency. These results confirm my two hypotheses, which I would like to restate here: (i) Yes, CLIL education, better than traditional approaches, can help students to score better results in language proficiency, and (ii) Yes, CLIL education leads learners to a better subject matter knowledge than traditional learning.

\section{DISCUSSION}

In recapitulation, I have concluded that CLIL students demonstrated a high level of proficiency in English with no grammatical and lexicon mistakes witnessed during my data recording at least. In my close scrutiny to the students' learning mechanisms, I have observed that CLIL environment motivates the learners to use new innovative techniques of learning such as 'collective learning' displayed in practicing and adopting new forms of grammar namely 'dialogical grammar'. CLIL environment offers also plenty of time to practice and stop at each unknown concept to research it. Unlike in traditional education systems, there is no way in CLIL education to jump over the meaning of concepts when they are not clear, i.e., the whole group of learners in addition to the teacher get involved in explanation of such concepts because its meanings are crucial to do the task at hand.

Would it be possible to introspect the minds of non-CLIL students I would hear them say: "why should we bother ourselves with a concept such as 'sub-sequent' knowing that we are not going to study mathematics later". Saying this would indeed be no mistake or sign of laziness because learning a language is not an extravagant task for them. In contrast, a CLIL student is obliged to learn this concept if she/he has to do the exercise and to make progress in the subject as whole. Indeed, it is at this meticulous and microscopic level of learning processes that the factor of motivation can be detected whether it is in operation or not, i.e., a student may judge him/herself to be motivated for learning a language but he/ she may not be aware whether he/she is motivated to learn this concept or that concept. That is to say, the motivation factor operates, in addition to the conscious and explicit levels, at a very deep unconscious and implicit level and is dictated not only by the will of the learner but also by 
the operational (or pedagogical) steps put in the learning process. The design of CLIL education is excellent for this, i.e., if a student wants to learn mathematics he/she must go through learning the language of instruction. Thus, language and subject matter are presented for CLIL students as one holistic package.

Furthermore, I deduced from the questionnaire I deployed that all the students were holding positive attitudes towards learning mathematics through English, these feelings might be explained by their awareness of the prospective and futuristic investment they are putting in CLIL education when they grow up and become open to international market. In addition, learning mathematics through English appears as a language game, i.e., the students have to find out the meaning of the concepts they are using if they have to do tasks of the subject matter. As such, it is more enjoyable and entertaining for them though it requires a bit of high workload.

As a consequence, the effect of learning mathematics in a CLIL environment is not limited only to language but it extends to the subject matter itself. We have seen in concrete terms that CLIL students scored higher than the control group on the same test on 'quadratic equations'. In addition to what could be said on the factors influencing students (of the two groups), I think that there are some strength aspects adhered to CLIL education. As a case in point, the fact that CLIL education offers 'repetition' of the syllabus learned in the mother tongue gives additional time and opportunity to the students to revise and fix what they have been learning in their mother tongue. Also, the fact that CLIL students learn the subject matter through a foreign language requires a special attention to the technical terms and this fact boosts their understanding of the concepts.

All in all, examining the whole parts and constituents of this research as one unified process makes it clear to me that CLIL education, put in juxtaposed comparison with other traditional types of education, offers a superior paradigm of education. Its superiority stems from the genuine idea of integrating learning a language with learning a subject matter. It seems, though not yet completely uncovered how, that there is a certain tradeoffin terms of the brain mechanisms involved in learning- between language and subject matter which is displayed in the mutual dependence to accomplish and hence attaining both language and subject matter. 


\section{CONCLUSION}

In this study, I have attempted to demonstrate in a practical way that CLIL education, shaped by its integrative model of content and language, is innovative in that it fosters creative learning of the subject matter through enhancing "variable repetition". It also creates an ideal context of learning languages which echoes the environment of learning the mother tongue through enhancing the pragmatic aspect of acquiring a language.

In terms of language proficiency, I concluded that CLIL education lead to a better language proficiency in the target language because it (CLIL) seems to activate implicit mechanisms of learning a language as displayed in students' simultaneous learning and practicing the target language. This manner of learning a language displayed in students' linguistic output which showed new ways of learning such as 'collective learning' and new linguistic structures such as 'dialogical syntax'.

In addition, I have observed that CLIL education creates a highly motivational atmosphere for learning new mathematical concepts and terminology by making language a prerequisite step in the learning process of the subject matter. In other words, the design of CLIL courses activates unconscious and implicit motivational mechanisms which depend not only on the conscious will of the learner but also on his unconscious will.

As far as concerning the subject matter, I concluded that CLIL lead to better subject matter knowledge than traditional learning. This conclusion has been demonstrated by the test I carried out with both groups. Add to that the teacher's continuous assessment, which represents a far more powerful tool of assessment, demonstrated that CLIL students have scored high marks, a sign of the students' positive response to CLIL education, compared to their peers.

In conclusion, I believe that the strengths and innovative aspects of CLIL education are displayed in: (i) cognitively, subject matter learning and language learning reciprocally benefit from each other in terms of the underlying brain mechanisms activated, (ii) psychologically, the language and content integrated design of CLIL education creates a highly motivational atmosphere for learning both languages and subject matter, (iii) structurally, allow the schools and classrooms to restructure and adopt new meth- 
ods and policies of teaching and learning, and (iv) socially, CLIL education fosters pluralinguistic society.

\section{REFERENCES}

Admiral, W., G. Westhoff, \& C. de Bot. (2006). Evaluation of Bilingual Secondary Education in The Netherlands: Students' language proficiency in English. Education Research and Evaluation 12(1), 75-93.

Baker, C. \& S. Prys Jones. (1998). Encyclopedia of Bilingulaism and Bilingual Education. Clevedon, Avon: Multilingual Matters.

Bamford, K. \& Mizokawa, D. (1991). Additive-bilingual (immersion) education: Cognitive and language development. Language Learning 41(3), 413-429.

Bialystok, E. (2005). The Impact of Bilingualism on Language and Literacy Development. In (eds.) Bhatia, T. K \& Titchie, W. C.,Handbook of Bilingualism (2006)Oxford: Blackwell, 577-602.

Bialystok, E., F. Craik \& M. Freedman. (2006). Blingualism as a protection against the onset of symptoms of dementia. Neuropsychologia 45, 459-464.

Burbaud, P., Degreze, P., Lafon, P., Franconi, J. M., Bouligand, B., Bioulac, et al. (1995). Lateralization of prefrontal activation during internal mental calculation: A functional magnetic resonance imaging study. Journal of Neuropsychology, 74, 2194-2200.

Byrnes, J. P. (2001). Minds, Brains, and Learning: Understanding the psychological and educational relevance of neuroscientific research. New York: Guilford Press.

Ceuleers, E. (in print) 'Variable Identities in Brussels. Language learning, motivation and identity of adolescents in a Dutch-speaking school in Brussels". Journal of Multilingual and Multicultural Development.

Cowell, S. F., Egan, G.F., Code, C., Harasty, J., \& Watson, J. D. (2000). The functional neuroanatomy of simple calculation and number repetition: A parametric PET activation study. Neuroimage, 12 565-573.

Dehaene, S., Spelke, E., Pinel, P., Stanescu, R., \& Tsivkin, S. (1999). Sources of Mathematical thinking: Behavioral and brain-imaging evidence. Science, 284, 970-974. 
Du Bois. W. J, S. Schuetze-Coburn, S. Cumming,\& D. Paolino (1993). Outline of discourse transcription. In J. Edwards \& M. D. Lampert (eds) Talking Data: Transcription and Coding in Discourse Research. Hillsdale: Lawrence Erlbaum Association.

Edwards, J. A. (2007). The Transcription of Discourse: The Handbook of Discourse Analysis. Blackwell Reference Online.

Genesee, F. (2003). Rethinking bilingual acquisition. In J.M. deWaele (Ed.) Bilingualism: Challenges and directions for future research. Clevedon, UK: Multilingual Matters (pp. 158-182).

Hiebert, J., \& LeFever, P. (1987). Conceptual and procedural knowledge in mathematics: An introductory analysis. In J. Hiebert (ed.), Conceptual and procedural knowledge in mathematics (pp.1-27). Hillsdale, NJ: Erlbaum.

Jappinen, A. K. (2005). Thinking and content learning of mathematics and science as cognitional development in content and language integrated learning (CLIL): Teaching through a foreign language in Finland. Language and Education. Vol. 19/2.

Lorenzo, F. S. Casal, \& P. Moore (2009). The effects of content and language integrated learning in European education: Key findings from the Andalusian bilingual sections evaluation project. Applied linguistics. Oxford University Press: 1- 25.

McLean, J. F. \& Hitch, G. J. (1999). Working memory impairments in children with specific arithmetic learning difficulties. Journal of Experimental Child Psychology, 74, 240 - 260.

Marsh, D. \& D. Wolff (eds) (2007). Diverse Contexts- Converging Goals. CLIL in Europe. Frankfurt am Main: Peter Lang, 185-200.

Murray, D. R. (2010) Irish-medium language immersion programs' effect on mathematics education. Journal of Mathematics Education at Teachers College, Fall-Winter Vol 1.

Van de Craen, P, E. Ceuleers \& K. Mondt. (2007a). 'Cognitive development and bilingualism in primary schools: teaching maths in a CLIL environment'. In: D. Marsh \& D. Wolff (eds) Diverse ContextsConverging Goals. CLIL in Europe. Frankfurt am Main: Peter Lang, 185-200. 
Van de Craen, P., K. Lochtman, E. Ceuleers, K. Mondt \& L. Allain. (2007b). CLIL An Interdisciplinary research approach to CLIL learning in primary schools in Brussels. In: C. Dalton-Puffer \& U. Smit (eds) Empirical Perspective on CLIL Classroom Discourse. Frankfurt am Main: Peter Lang, 253-274.

Van de Crean, P., K. Mondt, L. Allain \& Y. Gao. (2007c). Why and How CLIL Works. An Outline for a CLIL Theory. Vienna English Working Papers 16(3), 70-78.

Van de Cren, P., E. Ceuleers, K. Mondt \& L. Allain. (2008). European multilingual languages policies in Belgium and policy-driven research. In K. Lauridsen \& D. Toudic (eds) Languages at Work Festschrift in Honour of Wolfgang Mackiewicz. Gottingen: V

Yen-Ling Teresa Ting (2010). CLIL Appeals to How the Brain Likes Its Information: Examples From CLIL-(Neuro)Science International CLIL Research Journal Vol (1) 3

\section{ELECTRONIC REFERENCES}

http://www.sh-dilsen.be/joomla/

http://www.cs.columbia.edu/ sbenus/Teaching/APTD/Edwards transcription_Handbook_of_DA.pdf

http://oxforddictionaries.com/definition/english/ethnography? q=ethnography 


\section{APPENDIX 1}

\section{Data encoding}

Setting:

Place: SH school

Time: between 13:50 till 14:40

Lesson: Geometrical sequences.

Task: correcting exercises on geometrical sequences.

$\mathrm{T}$ : introducingthe intern (me).

$\mathrm{T}$ : Reminding and explaining [....]

1. T: so this exercise,

2. $\mathrm{S}_{1}$ : oh, yes

3. T: what is the first term of this sequence?

4. Ss: one

5. T: what is the second term?

6. $\mathrm{S}_{2}$ : one, two

7. T: which term will be the last one? The one becomes two, the two becomes three, so the $n$ ?

8. $\mathrm{S}_{3}: \mathrm{n}+1$

9. T: do you agree?

10. $\mathrm{S}_{4}$ : yes

11. T: what about six? Six is a problem..

12. $\mathrm{S}_{4}$ : I didn't understand the word-concept-contribution

13. T: ahaa! We have a problem in English, what is the meaning of the word contribution?

14. $\mathrm{S}_{5}$ : een bijdrage

15. T: een bijdrage, you translated it (teacher went to check in dictionary)

16. $\mathrm{S}_{6}$ : to contribute

17. T: to contribute is bijdrage, so khalid I show you how we do it.... A FIRM SPONOR ..

18. $\mathrm{S}_{2}$ : hesitate

19. T: but try to explain not to translate?

20. T: to give, a contribution is something you give

21. $\mathrm{S}_{3}$ : a gift, a donation..... 
22. [Teacher assists each student separately-each one raises a certain question-]

23. T: are there any questions?

24. T: why did you say it's seven?

25. $\mathrm{S}_{8}$ : because it is.. first sentence

26. $S_{9}$ : yeah! It's the same.

27. $\mathrm{S}_{10}$ : I didn't understand $\mathrm{R}$

28. T: [....] teacher explain problem,

29. T: did you find seven?

30. $\mathrm{S}_{2}$ : I think I have, yes I have it.

[work on the blackboard]

31. T: [...] you know what a subsequence is?

32. $\mathrm{S}_{1}$ : no

33. T: somebody knows it?

34. $\mathrm{S}_{3}$ : yes, the day after the day,

35. $\mathrm{T}$ : is the day after the day or the second day after the day....?

36. $\mathrm{S}_{3}$ : no, the days after the day

37. T: how do you translate it?

38. $\mathrm{S}_{5}$ : opvolgend

39. T: opvolgend.

40. T: [looking in the dictionary] occurring or coming later, following order, so I will type coming later.

[move to new exercise]

41. T: who can explain this?.....why $\mathrm{R}$ is equal to one or two?

42. $\mathrm{S}_{8}$ : because it increases with the percent.

43. $\mathrm{S}_{6}$ : I found seven...it was difficult..I couldn't follow your.. so I have..

44. [the teacher and a student discussing a problem..]

45. T: Lisa you can click here and expend the page

46. $\mathrm{S}_{2}$ : thanks

47. [Teacher explains when they will have next exam on geometrical sequences.....filling the questionnaires]. 


\section{APPENDIX 2}

\section{Questionnaire (Students' attitudes)}

This questionnaire is about students' attitudes towards learning mathematics in a CLIL environment. Please answer the questions below. If you did not understand something please don't hesitate to ask me. Thank you in advance.

\section{General information}

\begin{tabular}{|l|l|}
\hline What is your name? & \\
\hline What is your gender? & $\begin{array}{l}\text { Male } \\
\text { Female }\end{array}$ \\
\hline How old are you? & \\
\hline
\end{tabular}

\section{Linguistic background}

How many languages do you speak?

What is your mother tongue?

What are the languages do you speak?

How many years you have been studying English?

How good you were at English before you started learning Maths in English? (Put a cross in the appropriate answer)

\begin{tabular}{|c|c|c|c|c|}
\hline & Weak & Average & Good & Very good \\
\hline Speaking & & & & \\
\hline Listening & & & & \\
\hline Reading & & & & \\
\hline Writing & & & & \\
\hline
\end{tabular}

\section{Attitudes}

How important, you thought, learning Maths through English is (before CLIL)?

1. Not important

2. Neutral

3. Important

4. Very important 
How good is your English become after you start learning Maths through English? (Put a cross in the right answer)

\begin{tabular}{|c|c|c|c|c|}
\hline & Weak & Average & Good & Very good \\
\hline Speaking & & & & \\
\hline Listening & & & & \\
\hline Reading & & & & \\
\hline Writing & & & & \\
\hline
\end{tabular}

Do you like learning Maths in English? (Put a cross in the right answer)
1. Yes $\square$
2. No $\square$

If yes, how much do you like it? (Put a cross in the right answer)

1. Little bite

2. A lot

3. Very much

If no, why?

Do you speak English outside the classroom (circle the right answer?)

With teachers

With friends

Thank you very much no / sometimes / often / very often / always

no / sometimes / often / very often / always 


\section{APPENDIX 3}

\section{Mathematical test}

Stedelijke Humaniora and Koninklijk Atheneum Etterbeek
a. $6 x^{2}-150=0$
b. $4 x^{2}=-2 x$
C. $123 X^{2}=0$
d. $4 \chi^{2}+x=-8$

\section{APPENDIX 4}

\begin{tabular}{|c|c|c|c|c|c|c|c|c|c|c|c|}
\hline DW SEM2 & 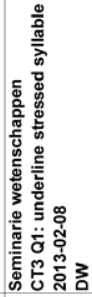 & 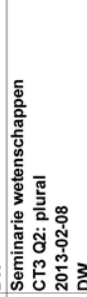 & 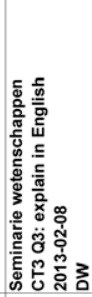 & 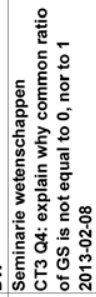 & 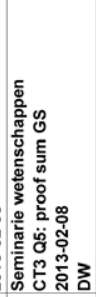 & 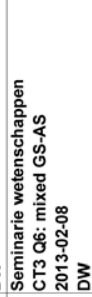 & 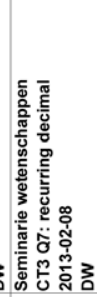 & 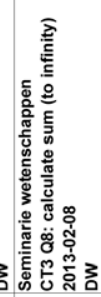 & 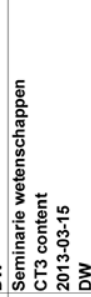 & 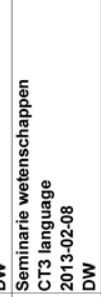 & 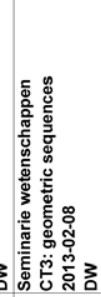 \\
\hline & 2 & 2 & 4 & 2 & 4 & 5 & 4 & 6 & 21 & 8 & "29 \\
\hline 5D3: klasgemiddelde & 1.4 & 1.9 & 2.4 & 1.6 & 3.5 & 4.7 & 3.5 & 3.9 & 17.2 & 5.7 & 22.8 \\
\hline 1. Breuls, Jordi & 1 & 1.5 & 1 & $\underline{0.5}$ & 3.5 & 5 & 4 & 3.5 & 16.5 & $\underline{3.5}$ & 20 \\
\hline 2. Didden, Lore & 2 & 2 & 1.5 & 1.5 & 3.5 & 5 & 4 & 3.5 & 17.5 & 5.5 & 23 \\
\hline 3. Dirkx, Ellen & 1 & 2 & 0.5 & 2 & 3 & 3.5 & 3.5 & 4 & 16 & $\underline{3.5}$ & 19.5 \\
\hline 4. Driesen, Claudia & 2 & 2 & 3 & 2 & 3 & 5 & 4 & 5.5 & 19.5 & 7 & 26.5 \\
\hline 5. Gevaert, Jasper & 1 & 2 & 3 & 1.5 & 3.5 & 5 & $\underline{0.5}$ & $\underline{2}$ & 12.5 & 6 & 18.5 \\
\hline 7. Herlitska, Lize & 2 & 2 & 3.5 & 2 & 3.5 & 5 & 4 & 3.5 & 18 & 7.5 & 25.5 \\
\hline 8. Jame, Joy & 2 & 2 & 3 & 2 & 3.5 & 4.5 & 4 & 4.5 & 18.5 & 7 & 25.5 \\
\hline 9. Oosterbos, Giel & 1 & 1 & 3 & 1.5 & 3.5 & 4 & 4 & 4 & 17 & 5 & 22 \\
\hline 10. Roussard, Michelle & 2 & 2 & 3.5 & 2 & 4 & 5 & 3 & 4.5 & 18.5 & 7.5 & 26 \\
\hline 11. Verdoodt, Marnick & $\underline{0}$ & 2 & 2 & 1 & 4 & 5 & 3.5 & 4.5 & 18 & 4 & 22 \\
\hline
\end{tabular}

